\title{
Mapping the Factors Influencing Success of Massive Open Online Courses (M0OC) in Higher Education
}

\author{
Nour Albelbisi ${ }^{1 *}$, Farrah Dina Yusop ${ }^{1}$, Umi Kalsum Mohd Salleh ${ }^{1}$ \\ ${ }^{1}$ University of Malaya, Kuala Lumpur, MALAYSIA
}

Received 23 January 2018 - Revised 16 April 2018 - Accepted 24 April 2018

\begin{abstract}
Massive Open Online Courses (MOOC) is a new phenomenon in online learning that has aroused increasing interest by researchers as a significant contribution to improving educational system quality and openness. The purpose of this paper is to compile and analyze MOOC research that has been published between 2012 and 2016. A systematic analysis technique was employed and Template Analysis (TA) approach was used for mapping $\mathrm{MOOC}$ research into three dimensions in accordance with the Biggs 3P model. First dimension is Presage, include the following factors: Learners' characteristics with sub-factors (learner demographics, learner motivation, and interactivity) and instructor. Second, Process, including factors of pedagogy, pattern of engagement, instructional design, assessment, credit, plagiarism, sustainability, and learning analytics. Third dimension is Product, including factors of student dropout rate and MOOC quality. This classification is aimed at providing a comprehensive overview for readers interested in MOOCs who seek to understand the critical success factors influencing MOOC success.
\end{abstract}

Keywords: MOOC, Massive Open Online Courses, MOOC success, MOOC quality

\section{INTRODUCTION}

Massive Open Online Courses (MOOC) is a new online learning style with significant capability to expand free online courses to a large number of participants worldwide. MOOC provides opportunities with no admission requirements to open up learning and to offer a wide range of choices in different areas and disciplines for a massive number of participants (Liyanagunawardena, Adams, \& Williams, 2013).

Since 2012, MOOC has received increased attention for its significant influence on lifelong learning as confirmed in the consequential Innovation Reports from the Open University, UK (Sharples et al., 2013, 2014). There is growing interest in MOOC by lifelong learners, higher education institutions, and for-profit platforms (Raffaghelli, Cucchiara, \& Persico, 2015) as manifested in Google trends for MOOC. Figure 1 displays a quick glance of Google Trends when searching for MOOC-related keywords.

A Scopus database was employed to explore the most-used terms as keywords in analysis related to MOOCrelated publications, as shown in Figure 2.

The result from searching the Scopus database revealed 491 publications in which 161 different keywords were used, with the most-used term being "MOOC", used in 113 publications, "Open Course" was used in 108, "Higher Education" in 96, "Massive Open Online Courses" in 59 and "Completion" in 32 publications.

Despite the fact that hundreds of thousands of people around the world are signing up for MOOC systems (Rivard, 2013) only few students complete courses and receive a certificate of completion. Some researchers estimated that the average completion rate of MOOC is below 10\% (Alraimi, Zo, \& Ciganek, 2015; Hew \& Cheung, 2014) while others suggest an even lower than $7 \%$ (Parr, 2013).

The main reasons for this high dropout rate may be associated with issues of MOOC systems related to courses, services, and education quality factors such as pedagogies, purposes, roles of instructors, learner motivations,

(C) 2018 by the authors; licensee Modestum Ltd., UK. This article is an open access article distributed under the terms and conditions of the Creative Commons Attribution License (http://creativecommons.org/licenses/by/4.0/).

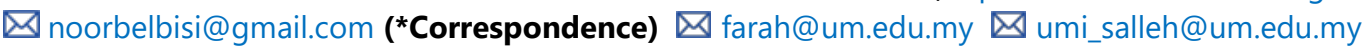




\section{Contribution of this paper to the literature}

- This study investigates and analyzes the key factors that impact success of MOOC system.

- This paper develops a map of classification that integrates critical factors influencing MOOC system success.

- This study reveals 12 main factors related to successful implementation of MOOC (e.g. learner characteristic, instructor).

\section{MOOC Massive open online course MOOCs}
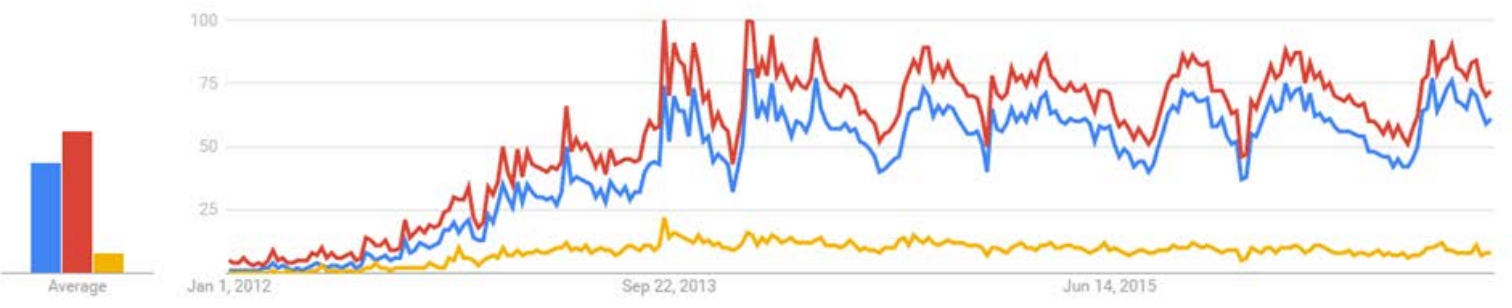

Figure 1. Google Trends for MOOC related keywords

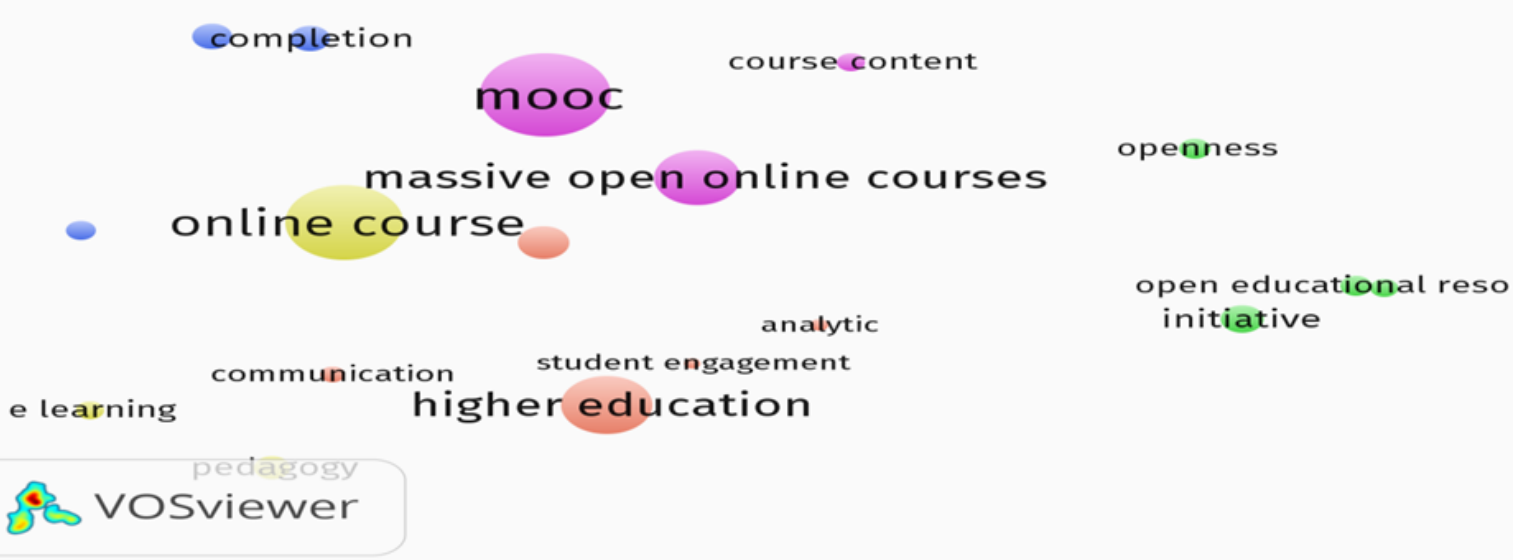

Figure 2. The most term used keyword in Scopus

expectations and behaviors (Milligan, Littlejohn, \& Margaryan, 2013) so measuring factors influencing MOOC should be considered a key issue in understanding MOOC success of lack thereof.

While there are widely available studies with empirical evidence that investigate factors influencing success of e-learning (e.g. Yusop, 2015; Yusop \& Siti Mariam, 2017), those factors may not be suitable for MOOC because of its the unique features (Gamage, Fernando, \& Perera, 2015). Therefore, research on the particular critical success factors of MOOC and dealing explicitly with MOOC participants would seem to be required (Yousef, Chatti, Schroeder, \& Wosnitza, 2014c). Most importantly, there is a critical need to examining the success factors of MOOC from a systemic point of view is virtually non-existent except for a study by Gamage et al. (2015). The current study has tried to fill in the current gap in literature by reporting results of a systematic literature review to explore the critical factors influencing success of MOOC systems. Identification of these factors will inform academics and higher education administrators in making informed decisions when adopting MOOC for their institutions and consequently reducing the percentage of failure in MOOC systems.

\section{LITERATURE REVIEW}

MOOC is recent phenomena in higher education, and its development is still in infancy, although the body of related research has been progressively growing. There are few systematic scholarly publications related to MOOC. These researches focused on providing descriptive analyses of MOOC literature such as its geographical 
distribution, publication outlets, citations (e.g. Liyanagunawardena et al., 2013; Veletsianos \& Shepherdson, 2016), and analyses of data collection and analysis methods used in researching MOOC (e.g. Bozkurt, Keskin, \& de Waard,2016; Veletsianos \& Shepherdson, 2016). Additionally, other previous researchers have been focusing on students' use of MOOC, mainly focusing on their motivations and challenges (e.g. Hew \& Cheung, 2014; Khalil \& Ebner, 2014). Others investigated characteristics related to MOOC (e.g. Liyanagunawardena et al., 2013).

While the above-mentioned articles seem to suggest that research topics on MOOC are diverse (Liyanagunawardena et al., 2013; Raffaghelli et al., 2015) and that the research interest about this topic is continually growing (Veletsianos \& Shepherdson, 2016) very little research has been done to understand critical factors influencing the success of MOOC. In view of this, there is a need for a review of relevant MOOC literature to gain a better understanding of the phenomenon.

\section{SIGNIFICANCE OF THE STUDY}

The current study represents the first effort to review the MOOC literature that has been published between 2012 and 2016 to understand the critical success factors influencing MOOC success and fills the gap in the literature in this domain. This study adds to the existing MOOC research by investigating in-depth the factors influencing MOOC success to promote successful implementation of MOOC systems within high education contexts.

By applying systematic review techniques, this study intends to contribute to a better understanding of MOOC literature by a mapping of publications related to factors influencing MOOC success based on Biggs's 3P framework to guide researchers, practitioners, institutions, international agencies, associations, and other networks (Anderson \& Zawacki-Richter, 2014).

\section{AIM OF THE STUDY}

Even though prior studies have emphasized the importance of MOOC success, there remains a lack of clarity about how MOOC could be successfully and effectively implemented. Moreover, little systematic empirical research has been directed towards thorough investigating and analyzing key factors that impact MOOC success (Gamage et al., 2015), so the primary aim of this study is to investigate factors influencing the success of MOOC.

The specific purpose of this paper is to analyze publications related to MOOC research that has been conducted during the period 2012-2016. A Template Analysis (TA) approach was used to map the conducted research on MOOC with the aim of providing an inclusive overview for readers interested in MOOC to increase their common understanding of critical success factors in this emerging field. This paper also aim to offer researchers interested in the subject a systematic view of the main publications and sources of scientific information related to MOOC.

Within this perspective, the research objectives for this study are as follows:

- To critically analyze the literature on MOOC.

- To identify critical factors influencing the success of MOOC.

- To develop a map of classification that integrates critical MOOC factors.

This study has been guided by the following research questions:

- What is the most active research published between 2012 and 2016 that has explored critical factors influencing MOOC success?

- What are the critical factors that influence the success of MOOC?

- How can critical MOOC factors be integrated into map classification?

\section{METHODS}

This study employed a systematic reviewing protocol to analyze and synthesize MOOC literature, followed by use of a template analysis approach (King, 2012) to map the conducted research on MOOC. Template Analysis is a technique used to thematically organize and analyze qualitative data. It has been applied extensively in social science researches (King, 2012).

Such systematic reviews are intended to provide guidance to researchers planning future studies, and provide convenient summaries of the literature on a particular issue (Petticrew \& Roberts, 2008).

In this systematic review, the literature search was based on the following procedures:

- First, the search terms chosen for recognition, based on Scopus analysis, included "MOOC", "MOOCs", "Massive Open Online Course", "Massive Open Online Courses" "MOOC Success”, and "MOOC Quality”. 
- Second, the search terms were used to search major refereed academic databases such as Web of science, Scopus, ERIC, Open Access Journals Search Engine (OAJSE), and Google Scholar. The current study focuses on these particular databases based on their multidisciplinary nature because they export data for bibliographic searching and literature research results in a standardized format.

- Third, select articles published from 2012-2016, a time frame chosen because MOOC studies in earlier years (before 2012) relied heavily on theoretical research (Hew \& Cheung, 2014) and generally reflected small sample sizes (Raffaghelli et al., 2015).

- Fourth, apply the following set of selection criteria for articles to be included in the review:

o The paper should be written in English and published in the period 2012-2016.

o Since, the primary focus of this review is on factors influencing MOOC success, learners' perceptions toward using MOOC, learners' characteristics, motivations, attitudes, engagement, satisfaction, and MOOC quality, these factors were included.

o Articles investigating stakeholders such as students and instructors were included, while papers examining other stakeholders such as employers, software engineers, and librarians were excluded.

o Articles not meeting the selection criteria, e.g., studies exploring political and policymakers' views or studies expressing personal opinions were excluded.

- Fifth, articles relevant to the topic of MOOC success and meeting the preceding criteria were selected based on information provided in their abstracts, followed by reviewing the full text of each article to eliminate articles not clearly related to MOOC systems success.

- Sixth, a secondary literature research was conducted by reviewing the references of each primary source to explore critical factors influencing success of MOOC.

Then, Template Analysis was used as the classification technique for mapping MOOC literature in several dimensions (King, 2012). Thematic analysis is perfectly appropriate to get a clear picture of the basic content of text. Thematic analysis is believed to be one of the most common methods to content analysis, where the coding scheme is based on categories designed to capture the dominant themes existing in the text (Attride-Stirling, 2001; Bryman \& Hardy, 2009). Therefore, the template analysis has been chosen purposefully as a document analysis process to foster the recurrent themes found in published articles on factors influencing success of MOOC in higher education. The template analysis has been done manually using printout tables based on four phases:

Phase one: reading the MOOC literature carefully to identify the studies that are familiar with the domain context.

Phase two: formulating codes (themes) based on understanding the studies domain and using existing MOOC classifications by Yousef, Chatti, Schroeder, and Wosnitza (2014b) and Hood and Littlejohn (2016) as a reference to test reliability. Yousef et al. (2014b) used templet analysis to map the research on MOOC into seven dimensions, namely concept, design, learning theories, case studies, business model, targets groups, and assessment. Hood and Littlejohn (2016) identified a range of variables that can be used to measure quality in MOOC using Biggs's (1993) 3P model.

Phase three: Categorizing and calculating the frequency of the critical MOOC factors influencing MOOC success according to Biggs's (1993) 3P model, three templates were identify as follows:

1. Presage that represents the input variables that related to teaching and learning process such as the learner characteristics and instructors.

2. Process which refers to the environment related with the presage variables (e.g. instructional design, and pedagogical approaches).

3. Product that represents the outputs of the educational outcomes such as completion rate.

Phase four: conducting several internal meetings to discuss combining and contrasting the findings from several studies into themes or coding in the textual data (e.g. Instructor, instructional design) then organized them in the templates (e.g. presage, process). Table 1 displays the classification of the studies included in this review according to the templates and themes. 
Table 1. Classification of selected MOOC papers based on Biggs's (1993) 3P model

\begin{tabular}{|c|c|c|}
\hline Template & Factor & Studies \\
\hline \multirow{4}{*}{ Presage } & $\begin{array}{l}\text { Learner } \\
\text { demographics }\end{array}$ & $\begin{array}{l}\text { (Christensen et al., 2013; DeBoer et al., 2014; Ho et al., 2014; Liyanagunawardena, et al., 2015; Morris, } \\
\text { 2014; Morris, Hotchkiss, \& Swinnerton, 2015). }\end{array}$ \\
\hline & $\begin{array}{l}\text { Learner } \\
\text { motivation }\end{array}$ & $\begin{array}{l}\text { (Abeer \& Miri, 2014; Belanger \& Thornton, 2013; Davis et al., 2014; Hew \& Cheung, 2014; Morris \& } \\
\text { Lambe, 2014; Wen, Yang, \& Rose, 2014b; Zheng, Rosson, Shih, \& Carroll, 2015). }\end{array}$ \\
\hline & interactivity & $\begin{array}{l}\text { (Conole, 2013; Grünewald et al., 2013; Guo, Kim, \& Rubin, 2014; Kolås, Nordseth\& Hoem, 2016; Li et } \\
\text { al., 2014; Mamgain et al., 2014). }\end{array}$ \\
\hline & Instructor & $\begin{array}{l}\text { (Adamopoulos, 2013; Evans \& Myrick, 2015; Ferguson \& Whitelock, 2014; Haavind \& Sistek- } \\
\text { Chandler, 2015; Najafi, Rolheiser, Harrison, \& Håklev, 2015; Rodriguez, 2012; Ross et al., 2014). }\end{array}$ \\
\hline \multirow{8}{*}{ Process } & Pedagogy & $\begin{array}{l}\text { (Ahn, Weng, \& Butler, 2013; Bayne \& Ross, 2014; Ferguson et al., 2015; Glance, Forsey \& Riley, 2013; } \\
\text { Istrate \& Kestens, 2015; Toven-Lindsey, Rhoads, \& Lozano, 2015; Yuan \& Powell, 2013). }\end{array}$ \\
\hline & $\begin{array}{l}\text { Pattern of } \\
\text { engagement }\end{array}$ & $\begin{array}{l}\text { (Anderson, Huttenlocher, Kleinberg, \& Leskovec, 2014; Ferguson \& Clow, 2015; Hew, 2014; Hill, 2013; } \\
\text { Kizilcec, Piech, \& Schneider, 2013; Milligan, Littlejohn, \& Margaryan, 2013; Nelson, 2014; Phan, } \\
\text { McNeil, \& Robin, 2016; Veletsianos et al., 2015; Waite, Mackness, Roberts, \& Lovegrove, 2013). }\end{array}$ \\
\hline & $\begin{array}{l}\text { Instructional } \\
\text { design }\end{array}$ & $\begin{array}{l}\text { (Amo, 2013; Chen, 2014; Downes, 2013; Lin et al., 2015; Littlejohn et al., 2016; Munoz-Merino et al, } \\
\text { 2015; Young, 2013). }\end{array}$ \\
\hline & Assessment & $\begin{array}{l}\text { (Admiraal, Huisman, \& Pilli, 2015; Admiraal, Huisman, \& Ven, van de, 2014; Clarà \& Barberà, 2014; } \\
\text { Kulkarni et al., 2013; Piech et al., 2013; Raposo-Rivas, Martinez-Figueira, \& Campos, 2015; Reilly, } \\
\text { Stafford, Williams, \& Corliss, 2014; del Mar Sánchez-Vera \& Prendes-Espinosa, 2015; Sandeen, } \\
\text { 2013a; Yousef et al., 2015e). }\end{array}$ \\
\hline & Credit & $\begin{array}{l}\text { (Billington \& Fronmueller, 2013; Bruff et al., 2013; El-Hmoudova, 2014; Green, 2013; Hollands \& } \\
\text { Tirthali, 2014; Jiang et al, 2014; Kursun, 2016; Sandeen, 2013b; Schulze , 2014; Shen \& Kuo, 2015). }\end{array}$ \\
\hline & plagiarism & $\begin{array}{l}\text { (Eisenberg, 2013; Maas et al, 2014; Marshall, 2014; Meyer \& Zhu, 2013; North, Richardson \& North, } \\
\text { 2014). }\end{array}$ \\
\hline & $\begin{array}{l}\text { Learning } \\
\text { analytics }\end{array}$ & $\begin{array}{l}\text { (Chandrasekaran, Ragupathi, Kan, \& Tan, 2015; Daradoumis, Bassi, Xhafa, \& Caballe, 2013; Kay, } \\
\text { Reimann, Diebold, \& Kummerfeld, 2013; Lackner, Ebner, \& Khalil, 2015; Tabba \& Medouri, 2013). }\end{array}$ \\
\hline & Sustainability & $\begin{array}{l}\text { (Aparicio, Bacao, \& Oliveira, 2014; Burd et al., 2014; Dellarocas \& van Alstyne, 2013; Kalman, 2014; } \\
\text { Parr, 2013). }\end{array}$ \\
\hline \multirow[t]{2}{*}{ Product } & $\begin{array}{l}\text { Student } \\
\text { dropout }\end{array}$ & $\begin{array}{l}\text { (Alraimi et al., 2015; Clow, 2013; Engle, Mankoff, \& Carbrey, 2015; Fischer, 2014; Freitas, Morgan, \& } \\
\text { Gibson, 2015; Greene, Oswald, \& Pomerantz, 2015; Hone \& El Said, 2016; Jordan, 2014; Khalil \& } \\
\text { Ebner, 2014; Mackness, Waite, Roberts, \& Lovegrove, 2013; Reich, 2014). }\end{array}$ \\
\hline & & $\begin{array}{l}\text { (Butcher et al, 2013; Gamage, Fernando, \& Perera, 2015; Hood \& Littlejohn, 2016; Jansen et al, 2016; } \\
\text { Margaryan, Bianco, \& Littlejohn, 2015; Yousef et al., 2014c). }\end{array}$ \\
\hline
\end{tabular}

\section{RESULTS}

In this section, we will present the results obtained from analysis and synthesis of information from the set of selected publications, using the procedures described above.

After eliminating unsuitable articles from both the initial and secondary literature searches, the final result of the systematic review study included a set of 102 publications matching the criteria. A PRISMA process was employed for the search, and Figure 3 displays the Preferred Reporting Items for Systematic Reviews and MetaAnalyses (PRISMA) flow diagram of critical success factors influencing MOOC. 


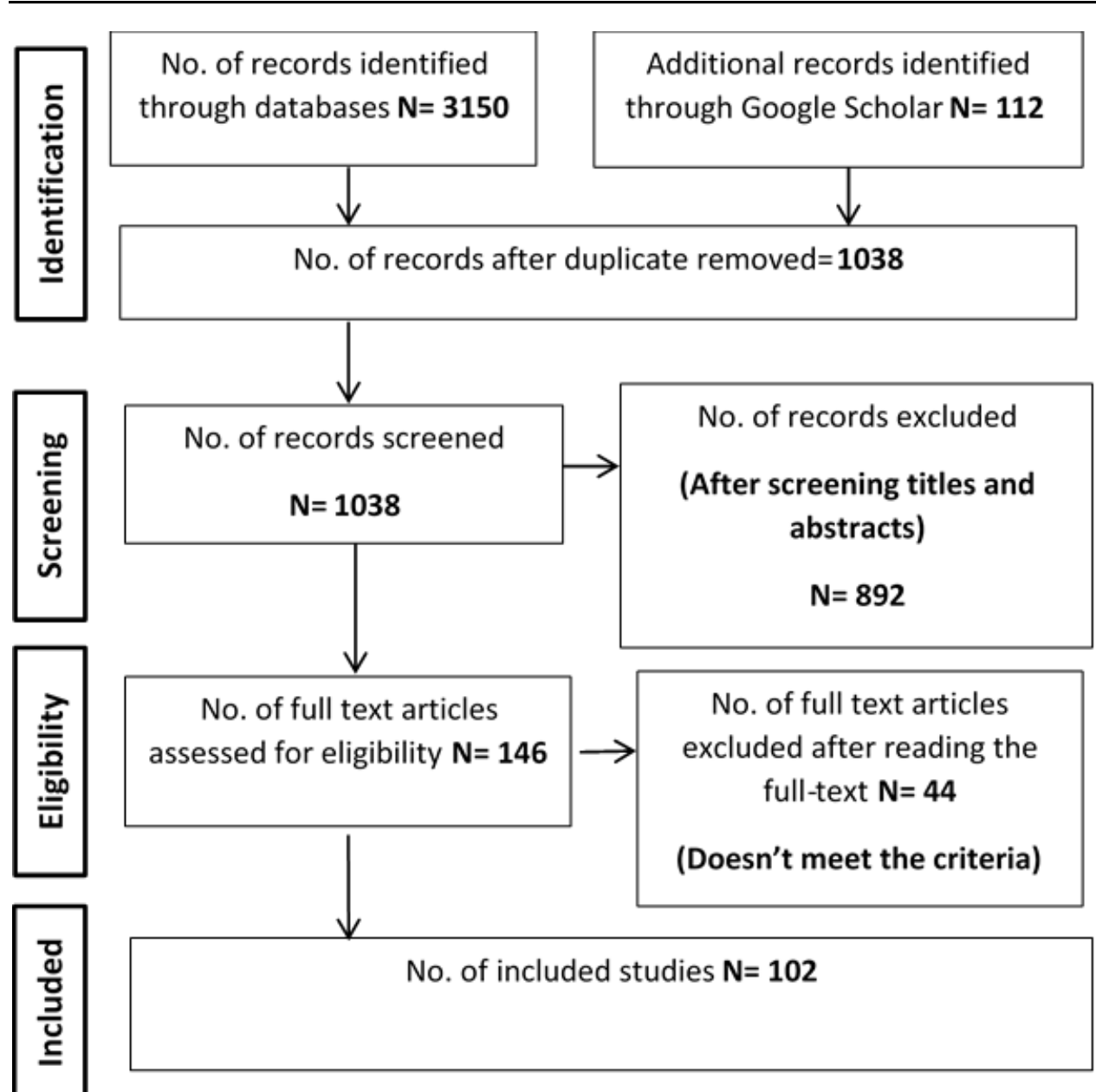

Figure 3. The PRISMA flow diagram of critical success factors influencing MOOC Source: Moher, Liberati, Tetzlaff, Altman, The PRISMA Group (2009)

Table 2. MOOC papers by publication year

\begin{tabular}{cccccc}
\hline & $\mathbf{2 0 1 2}$ & $\mathbf{2 0 1 3}$ & $\mathbf{2 0 1 4}$ & $\mathbf{2 0 1 5}$ & $\mathbf{2 0 1 6}$ \\
\hline No. of publication & 1 & 32 & 37 & 25 & 7 \\
\hline
\end{tabular}

102 studies were included in the data analysis, and each article identified was the basic unit of analysis. This analysis was conducted from year 2012 to 2016, and the collection of MOOC papers sorted by publication year is shown in Table 2.

From the 102 studies, 54 journal articles, 30 conference papers, 12 articles from Web magazines, 5 books, and 1 dissertation were considered as relevant and thus, included for further analyses as displayed in Figure 4. 


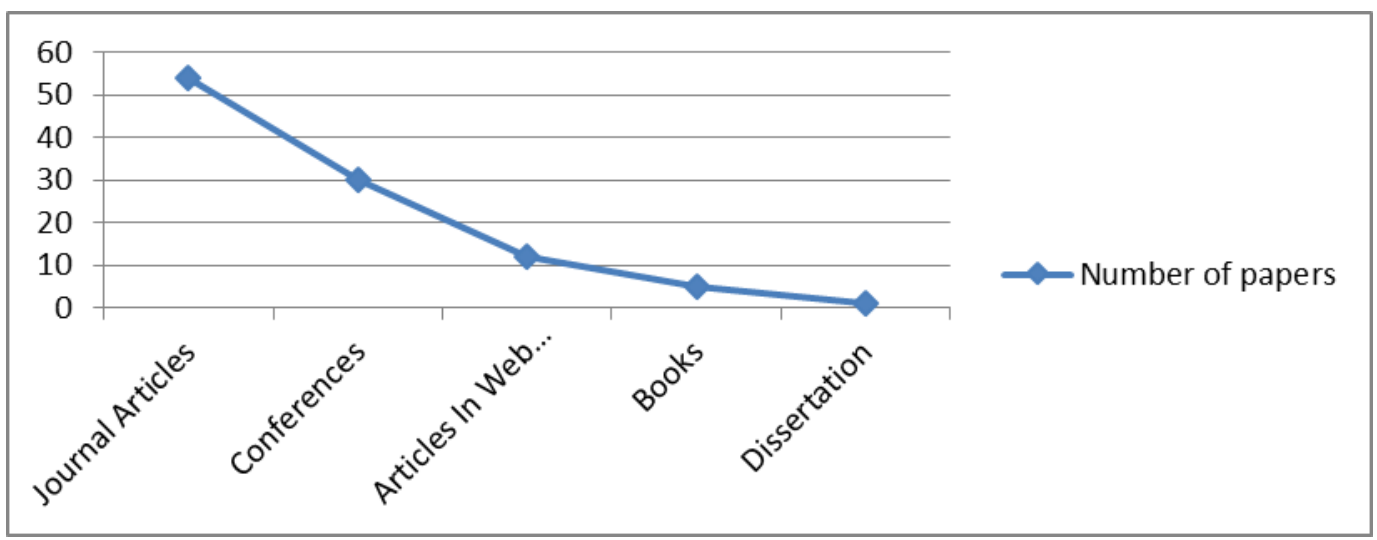

Figure 4. Distribution of articles by type of papers

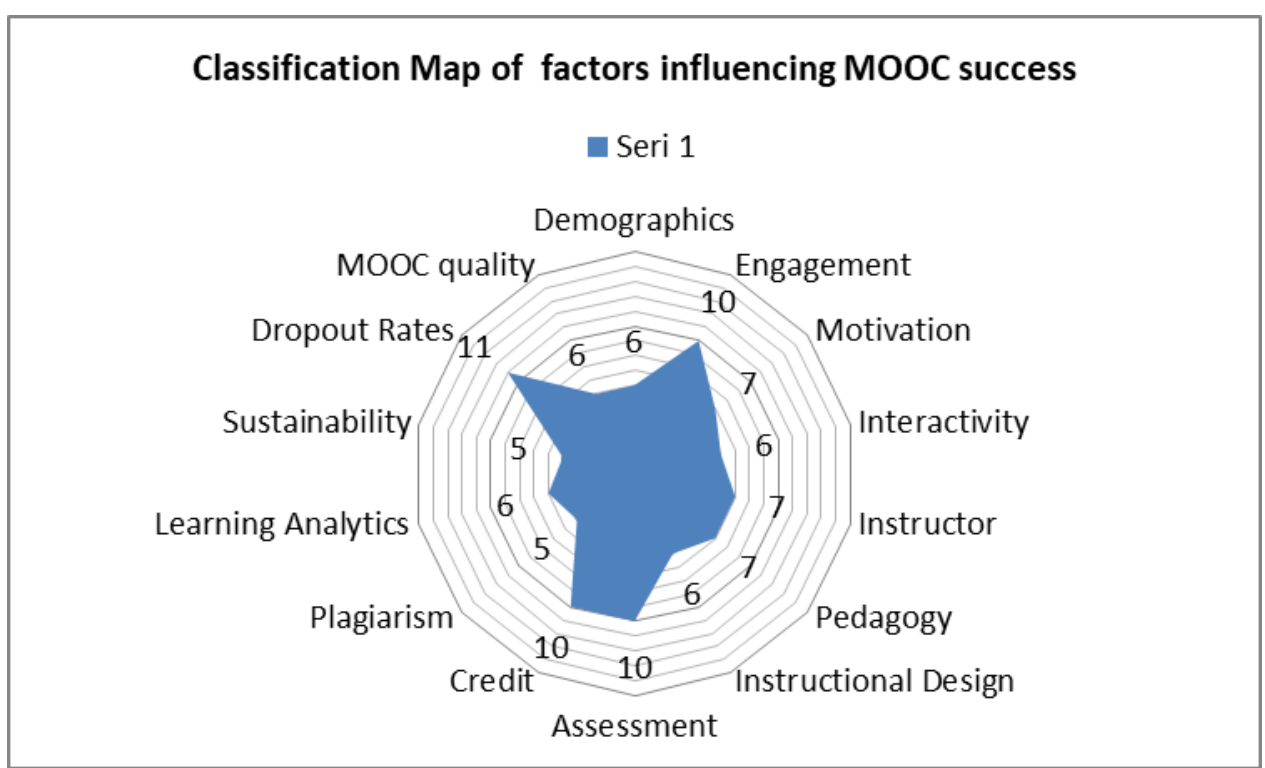

Figure 5. Classification map of factors influencing MOOC success

From this analysis, it can be observed that The International Review of Research in Open and Distributed Learning, Distance Education, Computers \& Education, British Journal of Educational Technology, and Journal of Online Learning and Teaching, were the top 5 journals publishing the greatest number of articles related to MOOC success.

All of the 102 publications that were selected in this review were then mapped into fourteen identified factors that influence the success of MOOC as displayed in the classification map of factors (Figure 5). For example, there were 11 studies that suggested dropout rates as the success factor, followed by engagement, credit and assessment (10 studies each); motivation, instructor, pedagogy (7 studies each); demographics, interactivity, instructional design, learning analytics and MOOC quality (6 studies each); and finally, plagiarism and sustainability (5 studies each).

\section{DISCUSSION}

After identifying critical factors influencing success of MOOC, Biggs's (1993) 3Pmodel was employed to determine the core components of a MOOC environment. The Biggs model suggests that to understand a particular ecosystem (Biggs, 1993) (e.g., MOOC), it is necessary to break it down into its components and examine how these components relate to one another and how they combine to form the system as a whole. The model divides each learning ecosystem into three types of variables: presage, process, and product. Presage represents input variables related to teaching and learning processes, including learners, motivation, demographics, and instructors. Process variables refer to the environment of the presage variables, including instructional design, and pedagogical approaches. Product variables are the outputs of the educational processes, e.g., outcomes such as completion rate. The Biggs's 3P model is displayed in Figure 6. 


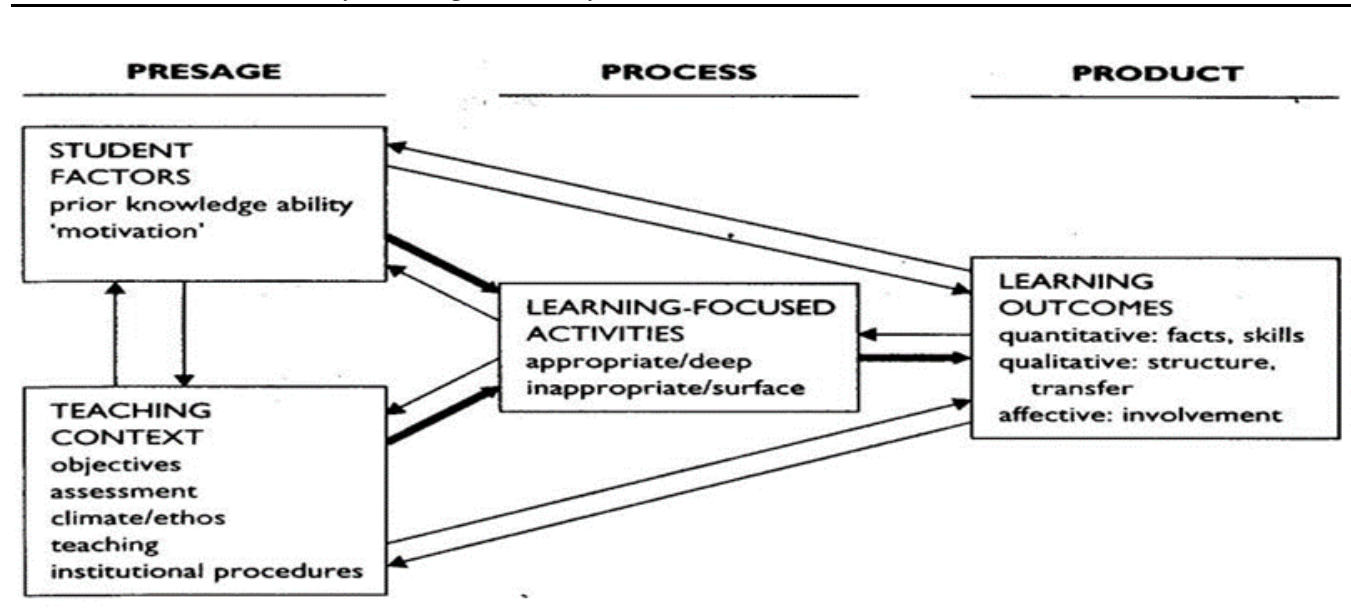

Figure 6. Biggs's 3P model

\section{Presage Variables}

The presage variables represent resources and factors related to teaching and learning processes. In the current study there are two (2) presage factors and three (3) sub-factors identified from the systematic literature review. They are:

\section{Learner characteristics}

Learner participation is one of the most-examined factors and debates in the MOOC literature. The literature reviewed revealed three sub-factors for learner characteristics: learner demographics, learner motivation, and interactivity.

\section{Learner demographics}

While a host of studies have investigated learner demographics, the current literature exploring MOOC currently are not attracting the diversity of learners originally expected. MOOC demographics show that most MOOC learners are already employed, are well-educated, are from developed countries and have been involved in higher education (DeBoer, Ho, Stump, \& Breslow, 2014; Liyanagunawardena, Lundqvist, \& Williams, 2015).

Christensen et al. (2013) conducted a study published by the University of Pennsylvania in November of 2013 that surveyed nearly 35,000 students from 200 countries who participated in 32 Coursera MOOC. Examining the demographic backgrounds of these MOOC learners revealed that $(83 \%)$ of participants had a post-secondary degree and $(79.4 \%)$ had a bachelor's degree or higher. $(40 \%)$ were under the age of 30, while fewer than $(10 \%)$ were over 60. There were significantly more males $(56.9 \%)$ than females, and (62.4\%) were employed full-time or selfemployed, with only $(13.4 \%)$ unemployed or retired.

\section{Learner motivation}

Motivation plays a vital role in student determination to enroll and continuously participate in MOOC. Wen, Yang, and Rose (2014b) confirmed that, the greater the learner motivation, the lower the risk of dropout.

Learners are motivated to join MOOC for different purposes. Common factors include: interest in the topic, access to free learning opportunities, a desire for refreshing knowledge, an opportunity to draw on world-class university knowledge, and gaining accreditation (Davis et al., 2014).

Hew and Cheung (2014) reported four reasons for why learners sign up for MOOC: a) interest in new technology, b) extending current knowledge, c) collecting as many completion certificates as possible, and d) learning as a personal challenge.

\section{Interactivity}

Interaction is the key to participant MOOC success (Khalil \& Ebner, 2014), and many researchers pointed out its importance in MOOC environments. Conole (2013) indicated that understanding how learners interact with MOOC should be considered. Kolås, Nordseth and Hoem (2016) pointed out that interactivity in MOOC motivates learning through enhancement of student engagement in a topic. 


\section{Instructor}

Instructors' motivation for MOOC instruction, their experience in teaching and developing MOOC, and their satisfaction in teaching MOOC have been investigated in many studies (Evans \& Myrick, 2015; Najafi, Rolheiser, Harrison \& Håklev, 2015). Ross, Sinclair, Knox, and Macleod (2014) argued for the importance of acknowledging the complexity of teacher roles and experiences in MOOC, and how they influence learner engagement.

Further research suggests that instructor participation in discussion forum activities during the execution of a MOOC activity can actively support learners and positively influence learning outcomes. Guo, Kim, and Rubin (2014) found that short videos, inclusion of instructor talking-head videos, and presence of drawing-hand style instructions were the most commonly useful factors for enhancement of student engagement in MOOC. Abeer and Miri (2014) found that student participation in MOOC can be affected by instructor-provided features, including clarity of explanations, visualization of abstract concepts, support and communication, and assignment variety.

\section{Process Variables}

Process variables refer to processes and actions related to the presage variables, and in this study eight (8) process variables were identified. They are:

\section{Pedagogy}

A host of studies (e.g., Toven-Lindsey, Rhoads, \& Lozano, 2015) have investigated MOOC pedagogy. The literature highlights that design MOOC should be clear, consistent, and coherent, and representing a well-defined pedagogical approach (Istrate \& Kestens, 2015).

MOOC has evolved into two different pedagogical styles: cMOOC and xMOOC. Broad attempts have been made to distinguish between these styles based on how teaching and learning takes place under their influence. cMOOC are classified with respect to their social mode of learning, while xMOOC are institutionally focused and dependent on video-lecture contents and automated assessment (Bayne \& Ross, 2014). cMOOC focuses on connection and collaborative learning while xMOOC emphasizes the extension of existing pedagogical models (Yuan \& Powell, 2013).

Because of the contrast between $\mathrm{CMOOC}$ and $\mathrm{xMOOC}$, the recent literature has begun to move away from separately considering these basic two styles of MOOC and more toward mediating the contrasts between them (Grunewald, Meinel, Totschnig, \& Willems, 2013).

\section{Pattern of engagement}

Student engagement in MOOC has achieved a significant interest in the literature (e.g. Phan, McNeil \& Robin, 2016). Many studies define engagement in terms of interaction of the learners with instructional materials such as lectures, manuscripts, and assessments, with the data obtained analyzed by different methods to determine trends and patterns in engagement with materials (e.g. Veletsianos, Collier, \& Schneider, 2015).

The literature has reported that the complexity and diversity of MOOC participants' perspectives and learner patterns are considered to be one main reason of a high MOOC dropout rate (Waite, Mackness, Roberts, \& Lovegrove, 2013), so an understanding of the different patterns of MOOC participants and their perspectives when participating in MOOC appears to be needed.

Hew (2014) studied the features of 965 course participants across three disciplines that have encouraged student engagement in MOOCs and suggested five that promote student engagement: problem-centric learning, instructor accessibility and passion, active learning, peer-interaction, and helpful course resources.

\section{Instructional design}

The literature has identified questions related to quality of MOOC courses (Chen, 2014) indicating the importance of using high-quality content resources and activities to create an effective instructional design (Amo, 2013). Designing a MOOC should be based on a participatory form to increase understanding of learner diversity and provide learning activities that support different learning styles and needs (Margaryan, Bianco, \& Littlejohn, 2015).

In addition, studies have recommended use of quality measures to assess both content and resource design and learner engagement. For instance, Munoz-Merino, Ruiperez-Valiente, Alario-Hoyos, Perez-Sanagustin, and Delgado Kloos (2015) suggested application of the Precise Effectiveness Strategy in a MOOC environment to evaluate effectiveness of learner interactions with educational resources and activities. 
Other examples of such frameworks that have been employed to address MOOC quality include: the Quality Matters guide (https://www.qualitymatters.org), iNACOL (http://www.inacol.org) and OpenUpEd (http://www.openuped.eu/images/docs/OpenupEd_quality_label_-_Version1_0.pdf). iNACOL, for example, is a framework that has been expanded to address MOOC. It includes multiple standards and rubrics for measuring quality course design, instruction, and programs.

\section{Assessment}

Assessment is an important factor in determining the future success of MOOC (Yousef et al., 2015e), and the ability to evaluate enormous number of learners in MOOC systems is considered a critical issue (Sandeen, 2013a). Most MOOC platforms offer assessment models such as peer assessment or online quizzes (Raposo-Rivas, Martinez-Figueira, \& Campos, 2015).

The quality of MOOC assessments has been evaluated by some authors. Admiraal, Huisman and Pilli (2015) examined the quality of the various assessment forms (quizzes, self-assessment and peer assessment of an essay) in three MOOCs and explored how these assessments were related to the final exams. The findings also revealed that completion of weekly quizzes was the strongest variable with respect to predicting final exam results.

\section{Credit}

MOOC literature has explored the rapid growth and interest in issues related to the effects of providing credit in MOOC learning environments (Kursun, 2016). Green (2013) indicated that if universities provide MOOC credits, this would create real potential for these certificates to be accepted in the real market. El-Hmoudova (2014) highlighted that providing formal course credit can decrease the dropout rate in MOOC.

Researchers debate how and whether university credit might be offered by MOOC (Bruff, Fisher, McEwen, \& Smith, 2013). The literature reveals that, although many MOOC offer certificates or badges for successful completion of a course, there is an absence of formal course credits (Shen \& Kuo, 2015). Moreover, a digital badge or a certificate provided by some MOOC platforms contains little value (Jiang et al., 2014), and a successful MOOC completion is not recognized as a formal credit by most universities (Billington \& Fronmueller, 2013).

Some educational entities, however, have recently become prepared to grant credits for MOOC. For example, the American Council on Education has approved some of the MOOC courses (Hollands \& Tirthali, 2014).

\section{Plagiarism}

The copyright issues and its impact on both instructors and learners such as using of copyright materials, course content ownership, and accessibility of open access materials are important factors affecting the future success of MOOC (Marshall, 2014). Many studies investigated plagiarism in MOOC (e.g. North, Richardson \& North, 2014) and found the main challenge to be how to validate original work and how to prevent plagiarism. It is important to verify the identity of each student to ensure that a person enrolling in a course is the person who takes the exam. Further research has explored technologies that could be employed to prevent cheating through techniques to ensure fair testing conditions (Meyer \& Zhu, 2013), and including technologies that confirm personal identity (Sandeen, 2013a) such as employing signature tracking.

\section{Sustainability}

Although MOOCs are providing free courses, they are not free to create or to support. For example, the University of Edinburgh, the first UK institution to join the Coursera platform, has spent on average, from development to delivery, about 45,000 USD on each course (Parr, 2013), thus demonstrating that MOOCs are certainly not free to create or offer, so it is important to identify ways in which MOOCs can generate income to cover such costs and become economically sustainable.

Many research studies have looked at models that would contribute to the sustainability of MOOCs and support MOOCs platforms. Aparicio, Bacao, and Oliveira (2014), for instance, identify sponsorship and data analytics as potential main streams of revenue for MOOCs. Burd, Smith, and Reisman (2014) suggested that charging a fee for certification, connecting students with employers, and charging a fee for extra services are business models that could be appropriate for MOOCs. Their suggestions are aligned with Dellarocas and van Alstyne (2013) who proposed that any institution offering MOOCs should consider various different groups such as students, employers, sponsors, and other platforms who could be expected to pay for MOOCs. 


\section{Learning analytics}

Learning analytics represent a potential for offering insight into learner and instructor participation in collaborative and interactive activities in MOOCs by providing both individual and general information for supporting learning experiences.

Several studies have suggested applying learning analytics tools to better personalize and fit MOOCs to learners (Daradoumis, Bassi, Xhafa, \& Caballe, 2013; Lackner, Ebner, \& Khalil, 2015; Tabba \& Medouri, 2013) and to support learners in their individual learning experiences (Yousef et al., 2014c). Ebben and Murphy (2014) provide a systematic review of MOOCs, highlighting the growth of learning analytics along with the process of delivering MOOCs.

\section{Product Variables}

Product variables are the outputs or outcomes of the educational processes. The results of this study suggest the following two (2) product variables related to MOOCs:

\section{Student dropout rate}

MOOC completion is an active area in MOOCs literature, and there is a significant volume of published research on this problem (e.g. Fischer, 2014). Studies indicated that MOOCs are facing high dropout rates (Alraimi et al., 2015; Clow, 2013) with only about 3-10\% of students successfully completing the MOOCs (Jordan, 2014).

Many studies have examined the reasons behind MOOCs low retention rates. Clow (2013) asserted that learners pass through the following four stages of dropout in MOOCs associated with a funnel of participation: awareness, registration, activity, and progress. Awareness occurs when potential participants learn about the MOOCs. A small fraction of these potential participants then enter the phase of registration to sign up to take the course. A small fraction of registrants then engage in an activity phase and actively participate in the MOOCs. Finally, only a small fraction of active registrants makes adequate progress and completes a MOOC course.

Other researchers such as Mackness, Waite, Roberts, and Lovegrove (2013) explored the direct factors of autonomy and learner involvement influencing completion of MOOCs. Greene, Oswald, and Pomerantz (2015) also investigated factors that affect learner retention and the characteristics of the participants within MOOCs, revealing that prior experience of MOOC and self-rated commitment to completing a course were the most statistically significant predictors of outcome.

\section{MOOCs quality}

MOOCs quality have not yet been clearly defined in the literature and should be more completely investigated (Yousef et al., 2014c). A study by Gamage et al. (2015) is a testament to this matter. They conducted a literature review that studied 4745 peer-reviewed publications in the period (2012-2015) to determine MOOC quality factors, and the findings revealed a significantly small amount of empirical evidence with respect to this issue. Only 26 papers were found to be highly-relevant with respect to examining MOOC quality. From 26 publications, only 7 were provided with proposal frameworks and only 3 offered quality dimensions supported with empirical evidence.

Furthermore, there is a lack of agreement on the most suitable measurement of quality in MOOC (Hood \& Littlejohn, 2016) which may explain the limited studies examining critical success factors of MOOC (Gamage et al., 2015). Most of the MOOC literature describes measurement of MOOC quality by assessing completion rates (e.g. Hone \& El Said, 2016), but other research (i.e. Littlejohn, Hood, Milligan, \& Mustain, 2016) suggests that such a variable (e.g., completion) is not always the goal of individual learners and not really compatible with satisfaction or learner perceptions of successful learning and therefore is not considered an appropriate measure of the quality of learning.

Evaluating MOOC learning requires development of new measures of success and quality that include diversity with respect to both participant and intentions (Bayne \& Ross, 2014). MOOC quality can be viewed and measured in various ways. DeBoer et al. (2104) suggested that evaluating participation and achievement in MOOC should be in accordance with the diverse motivations, goal orientations and actions of participants, thus reflecting the dimensions of MOOC quality (Hood \& Littlejohn, 2016).

\section{CONCLUSIONS}

Although the MOOC movement is gaining in popularity in higher education contexts, this does not necessarily mean that higher education institutions should immediately join the bandwagon. The purpose of this research has 


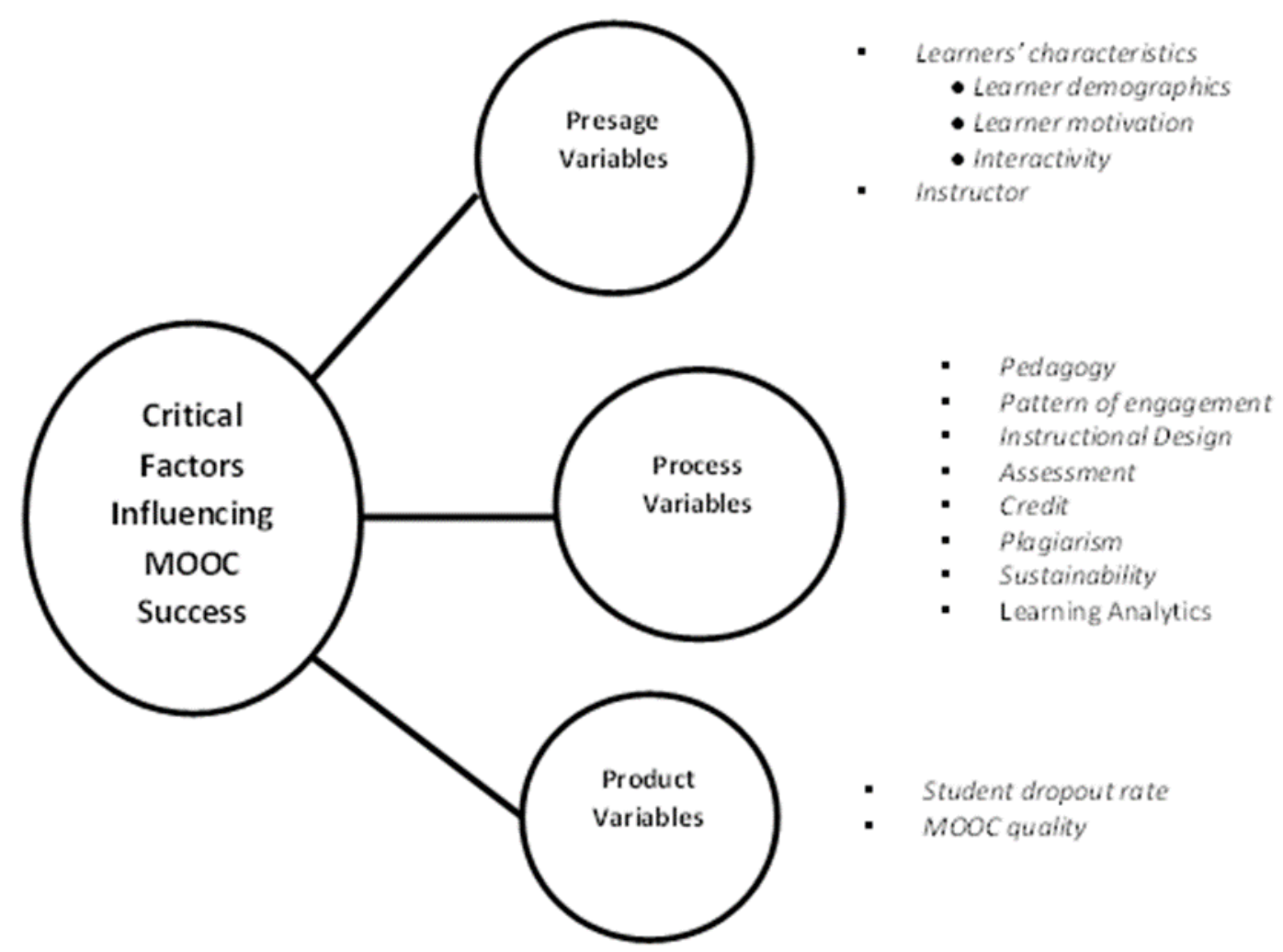

Figure 7. The critical factors influencing MOOC success

been to analyze and map publications related to MOOC research to better understand factors influencing MOOC success. A systematic literature review approach was used to identify and analyze key factors that impact MOOC success.

The findings of this study reveal 12 main factors related to successful implementation of MOOC. They are: Learner characteristic with sub-factors (learner demographics, learner motivation, and interactivity), instructor, pedagogy, pattern of engagement, instructional design, assessment, credit, plagiarism, sustainability, learning analytics, student dropout rate, and MOOC quality. These factors are classified into three levels: presage, process, and product variables, according to Biggs 3P model as displayed in Figure 7.

Consideration of these elements will ensure that the MOOC is designed and delivered effectively to ensure meaningful learning occurs and result in learning satisfaction among MOOC learners, thereby achieving success with MOOC systems.

Another important thing worth highlighting is that, as in any e-learning movement, enculturation of MOOC will require full participation from all the actors involved, especially the instructors and learners. Special attention needs to be given to recruitment, training, and support for instructors involved in such initiative (Ghaffar et al., 2016) to ensure that they are ready and fully-armed with the pedagogical approaches needed in planning and implementing MOOC to result in satisfaction and meaningful learning experiences for MOOC learners.

\section{ACKNOWLEDGEMENTS}

This study has been supported by the University of Malaya research grants (no. RU022C-2014 and RU008T2017).

\section{REFERENCES}

Abeer, W., \& B. Miri, B. (2014). Students' preferences and views about learning in a MOOC. Procedia - Social and Behavioral Sciences, 152, 318-323. https:// doi.org/10.1016/j.sbspro.2014.09.203

Adamopoulos, P. (2013). What makes a great MOOC? An interdisciplinary analysis of student retention in online courses, Paper presented at the Thirty Fourth International Conference on Information Systems, Milan. 


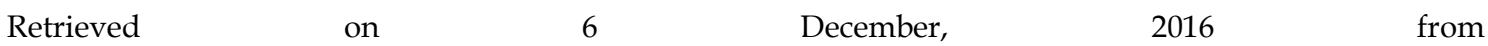
http:/ / pages.stern.nyu.edu/ padamopo/What\%20makes\%20a\%20great\%20MOOC.pdf

Admiraal, W., Huisman, B., \& Pilli, O. (2015). Assessment in Massive Open Online Courses. Journal of e-Learning, 13(4), 207-216. Retrieved from http:/ / www.ejel.org

Admiraal, W., Huisman, B., \& Ven, M. van de (2014). Self- and peer assessment in Massive Open Online Courses. International Journal of Higher Education, 3(3), 119-128. https:/ / doi.org/10.5430/ijhe.v3n3p119

Ahn, J., Weng, C., \& Butler, B. S. (2013, January). The dynamics of open, peer-to-peer learning: what factors influence participation in the P2P University? In System Sciences (HICSS), 2013 46th Hawaii International Conference on (pp. 3098-3107). IEEE, Wailea, Maui, HI.

Alraimi, K. M., Zo, H., \& Ciganek, A. P. (2015). Understanding the MOOCs continuance: The role of openness and reputation. Computers $\mathcal{E}$ Education, 80, 28-38. https://doi.org/10.1016/j.compedu.2014.08.006

Amo, D. (2013). MOOCs: Experimental Approaches For Quality in Pedagogical and Design Fundamentals. TEEM '13, November 14 - 15 2013, Salamanca, Spain. https:/ / doi.org/10.1145/2536536.2536570

Anderson, A., Huttenlocher, D., Kleinberg, J., \& Leskovec, J. (2014, April). Engaging with massive online courses. In Proceedings of the 23rd international conference on World wide web (pp. 687-698). ACM. https:/ / doi.org/10.1145/2566486.2568042

Anderson, T., \& Zawacki-Richter, O. (2014). Conclusion: Towards a Research Agenda. In O. ZawackiRichter \& T. Anderson (eds.), Online distance education: Towards a research agenda (p. 485- 492). Edmonton, Canada: AU Press. https:/ / doi.org/10.1057/9781137455970

Aparicio, M., Bacao, F., \& Oliveira, T. (2014, May). MOOC's business models: Turning black swans into gray swans. Proceedings of the International Conference on Information Systems and Design of Communication (pp. 45-49). https:/ / doi.org/10.1145/2618168.2618175

Attride-Stirling, J. (2001). Thematic networks: an analytic tool for qualitative research. Qualitative research, 1(3), 385 405. https:/ / doi.org/10.1177/146879410100100307

Bayne, S., \& Ross, J. (2014). The pedagogy of the Massive Open Online Course: the UK view. The Higher Education Academy, $1-76$. Retrieved

from https://www.heacademy.ac.uk/system/files/hea_edinburgh_mooc_web_240314_1.pdf

Belanger, Y., \& Thornton, J. (2013). Bioelectricity: a quantitative approach Duke University's first MOOC. Retrieved from

http:/ / dukespace.lib.duke.edu/dspace/bitstream/handle/10161/6216/duke_bioelectricity_mooc_fall201 2.pdf? sequence $=1$

Biggs, J. (1993). From theory to practice: A cognitive systems approach. Higher Education Research E Development, 12(1), 73- 85. https:/ / doi.org/10.1080/0729436930120107

Billington, P. J., \& Fronmueller, M. P. (2013). MOOCs and the future of higher education. Journal of Higher Education Theory and Practice, 13(3/4), 36-43. Retrieved from http://nabusinesspress.homestead.com/JHETP/BillingtonPJ_Web13_3_4_.pdf

Bozkurt, A., Keskin, N. O., \& de Waard, I. (2016). Research Trends in Massive Open Online Course (MOOC) Theses and Dissertations: Surfing the Tsunami Wave. Open Praxis, 8(3), 203-221. https:// doi.org/10.5944/openpraxis.8.3.287

Bruff, D. O., Fisher, D. H., McEwen, K. E., \& Smith, B. E. (2013). Wrapping a MOOC: Student perceptions of an experiment in blended learning. MERLOT Journal of Online Learning and Teaching, 9(2), 187-199. Retrieved from http:/ /jolt.merlot.org/vol9no2/bruff_0613.pdf

Bryman, A., \& Hardy, M. A. (Eds.). (2009). Handbook of data analysis. Sage.

Burd, E. L., Smith, S. P., \& Reisman, S. (2014). Exploring Business Models for MOOCs in Higher Education. Innovative Higher Education, 40(1), 37-49. https:/ / doi.org/10.1007/s10755-014-9297-0

Butcher, N., Hoosen, S., Uvalić-Trumbić, S., \& Daniel, J. (2014). A guide to quality in post-traditional online higher education. Dallas, Academic Partnerships.

Chandrasekaran, M., Ragupathi, K., Kan, M., \& Tan, B. (2015, December). Towards feasible instructor intervention in MOOC discussion forums. Paper presented at the Thirty-Sixth International Conference on Information Systems, Fort Worth, TX.

Chen, Y. (2014). Investigating MOOCs through blog mining. The International Review of Research in Open and Distributed Learning, 15(2). https:/ / doi.org/10.19173/irrodl.v15i2.1695 
Christensen, G., Steinmetz, A., Alcorn, B., Bennett, A., Woods, D., \& Emanuel, E. J. (2013). The MOOC Phenomenon: Who Takes Massive Open Online Courses and Why? Working Paper. Retrieved from http:/ / papers.ssrn.com/sol3/papers.cfm?abstract_id=2350964

Clarà, M., \& Barberà, E. (2014). Three problems with the connectivist conception of learning. Journal of Computer Assisted Learning, 30(3), 197-206. https:/ / doi.org/10.1111/jcal.12040

Clow, D. (2013, April). MOOCs and the funnel of participation. In Proceedings of the Third International Conference on Learning Analytics and Knowledge (pp. 185-189). ACM. https:/ / doi.org/10.1145/2460296.2460332

Conole, G. (2013). MOOCs as disruptive technologies: strategies for enhancing the learner experience and quality of MOOCs. RED. Revista de Educación a Distancia, (50). http:/ / hdl.handle.net/10760/19388

Daradoumis, T., Bassi, R., Xhafa, F., \& Caballe, S. (2013). A review on massive eLearning (MOOC) design, delivery and assessment. In Proceedings - 2013 8th International Conference on P2P, Parallel, Grid, Cloud and Internet Computing, 3PGCIC 2013 (pp. 208-213). Piscataway, NJ: IEEE. https:/ / doi.org/10.1109/3PGCIC.2013.37

Davis, H., Dickens, K., Leon, M., del Mar Sanchez Ver, M., \& White, S. (2014). MOOCs for universities and learners: An analysis of motivating factors. In 6th International Conference on Computer Supported Education 01- 03 Apr 2014.

DeBoer, J., Ho, A. D., Stump, G. S., \& Breslow, L. (2014). Changing "course" reconceptualizing educational variables for massive open online courses. Educational Researcher, https:/ / doi.org/10.3102/0013189X14523038

del Mar Sánchez-Vera, M., \& Prendes-Espinosa, M. P. (2015). Beyond objective testing and peer assessment: alternative ways of assessment in MOOCs. International Journal of Educational Technology in Higher Education, 12(1), 119-130. https:/ / doi.org/10.7238/rusc.v12i1.2262

Dellarocas, C., \& van Alstyne, M. (2013). Money models for MOOCs. Communications of the ACM, 56(8), 25-28. https://doi.org/10.3102/0013189X14523038

Downes, S. (2013). The quality of massive open online courses. International Handbook of E-learning, 1, 65-77. Retrieved from http://mooc.efquel.org/files/2013/05/week2-The-quality-of-massive-open-onlinecourses-StephenDownes.pdf

Ebben, M., \& Murphy, J. S. (2014). Unpacking MOOC scholarly discourse: a review of nascent MOOC scholarship. Learning, Media and Technology, 39(3), 328-345. https:/ / doi.org/10.108 0/17439884.2013.878352

Eisenberg, A. (2013, March 2). Keeping an eye on online test-takers. New York Times, 2. Retrieved from http://www.nytimes.com/2013/03/03/technology/new-technologies-aimto-foil-online-coursecheating.html

El-Hmoudova, D. (2014). MOOCs motivation and communication in the cyber learning environment. ProcediaSocial and Behavioral Sciences, 131, 29-34. https:/ / doi.org/10.1016/j.sbspro.2014.04.074

Engle, D., Mankoff, C., \& Carbrey, J. (2015). Coursera's introductory human physiology course: Factors that characterize successful completion of a MOOC. The International Review of Research in Open and Distributed Learning, 16(2). https:/ / doi.org/10.19173/irrodl.v16i2.2010

Evans, S., \& Myrick, J. G. (2015). How MOOC instructors view the pedagogy and purposes of massive open online courses. Distance Education, 36(3), 295-311. https:/ / doi.org/10.1080/01587919.2015.1081736

Ferguson, R., \& Clow, D. (2015, March 16-20). Examining engagement: analyzing learner subpopulations in Massive Open Online Courses (MOOCs). LAK'15 94 Proceedings of Fifth International Conference on Learning Analytics and Knowledge (pp. 51-58). Poughkeepsie, NY, USA.

Ferguson, R., \& Whitelock, D. (2014, September). Taking on different roles: how educators position themselves in MOOCs. In European Conference on Technology Enhanced Learning (pp. 562-563). Geneva, Switzerland: Springer, Cham. https://doi.org/10.1007/978-3-319-11200-8_70

Ferguson, R., Clow, D., Beale, R., Cooper, A. J., Morris, N., Bayne, S., \& Woodgate, A. (2015). Moving through MOOCS: pedagogy, learning design and patterns of engagement. In Design for teaching and learning in a networked world (pp. 70-84). Switzerland: Springer. https://doi.org/10.1007/978-3-319-24258-3_6

Fischer, G. (2014). Beyond hype and underestimation: Identifying research challenges for the future of MOOCs. Distance Education, 35(2), 149-158. https:/ / doi.org/10.1080/01587919.2014.920752

Freitas, S. I., Morgan, J., \& Gibson, D. (2015). Will MOOCs transform learning and teaching in higher education? Engagement and course retention in online learning provision. British Journal of Educational Technology, 46(3), 455-471. https:/ / doi.org/10.1111/bjet.12268

Gamage, D., Fernando, S., \& Perera, I. (2015, August). Quality of MOOCs: A review of literature on effectiveness and quality aspects. In Ubi-Media Computing (UMEDIA), 2015 8th International Conference on (pp. 224-229). IEEE. https:/ / doi.org/10.1109/UMEDIA.2015.7297459 
Ghaffar, F. A., Yusop, F. D., Sulaiman, A. H., Hassan, Z. F. A., Hamzaid, N. A., Firdaus, A. S., Hassim, N. (2016). Preparing Academics for Open Access Education: UM's Journey from Moodle to MOOCs. Paper presented at the Association of Southeast Asian Institutions of Higher Learning (ASAIHL), Universiti Putra Malaysia, Malaysia.

Glance, D. G., Forsey, M., \& Riley, M. (2013). The pedagogical Foundations of Massive Open Online Courses. First Monday: Peer-Reviewed Journal on the Internet, 18(5). https:/ / doi.org/10.5210/fm.v18i5.4350

Green, K. (2013). Mission, MOOCs \& money. AGB, Trusteeship Magazine, 21(1), 915. https://www.agb.org/trusteeship/2013/januaryfebruary/mission-moocs-money

Greene, J. A., Oswald, C. A., \& Pomerantz, J. (2015, May 8). Predictors of retention and achievement in a massive open online course. American Educational Research Journal (Online First). https:/ / doi.org/10.3102/0002831215584621

Grunewald, F., Meinel, C., Totschnig, M., \& Willems, C. (2013). Designing MOOCs for the support of multiple learning styles. In D. H. Leo et al. (Eds.), Scaling up learning for sustained impact (pp. 371-382). Berlin, Germany: Springer. https://doi.org/10.1007/978-3-642-40814-4_29

Guo, P. J., Kim, J., \& Rubin, R. (2014). How video production affects student engagement: an empirical study of MOOC videos. Proceedings of the first ACM conference on Learning@ scale conference March 4- 5, 2014 (pp. 4150). Atlanta, GA, USA. https:/ / doi.org/10.1145/2556325.2566239

Haavind, S., \& Sistek-Chandler, C. (2015). The Emergent Role of the MOOC Instructor: A Qualitative Study of Trends toward Improving Future Practice. International Journal on E-Learning, 14(3), 331-350.

Hew, K. (2014). Promoting engagement in online courses: What strategies can we learn from three highly rated MOOCS. British Journal of Educational Technology, 47(2), 320-342. https:// doi.org/10.1111/bjet.12235

Hew, K. F., \& Cheung, W. S. (2014). Students' and instructors' use of massive open online courses (MOOCs): Motivations and challenges. Educational Research Review, 12, 45-58. https:/ / doi.org/10.1016/j.edurev.2014.05.001

Hill, P. (2013). Emerging Student Patterns in MOOCs: A Graphical View. e-Literate. Retrieved from http:/ / mfeldstein.com/emerging_student_patterns_in_MOOCs_graphical_view /

Ho, A. D., Reich, J., Nesterko, S. O., Seaton, D. T., Mullaney, T., Waldo, J., \& Chuang, I. (2014). HarvardX and MITx: The first year of open online courses, fall 2012 - summer 2013. HarvardX and MITx Working Papers, No. 1. https://doi.org/10.2139/ssrn.2381263

Hollands, F. M., \& Tirthali, D. (2014). MOOCs: Expectations and reality: Full report. New York, NY: Columbia University. Retrieved from http://www.cbcse.org/wordpress/wpcontent/.../2014/05/MOOCs_Expectations_and_Reality.pdf

Hone, K., \& El Said, G. (2016). Exploring the factors affecting MOOC retention: A survey study. Computers $\mathcal{E}$ Education, 98, 157-168. https:/ / doi.org/10.1016/j.compedu.2016.03.016

Hood, N., \& Littlejohn, A. (2016). Quality in MOOCs: Surveying the Terrain. Retrieved from http:/ / oasis.col.org/bitstream/handle/11599/2352/2015_QualityinMOOCs-Surveying-theTerrain.pdf?sequence $=1 \&$ is Allowed $=y$

Istrate, O., \& Kestens, A. (2015, April). Developing and monitoring a MOOC: The IFRC experience. Paper presented at the 11th International Scientific Conference eLearning and Software for Education, Bucharest, Romania. Retrieved

from http://www.academia.edu/14707457/DEVELOPING_AND_MONITORING_A_MOOC_THE_IFRC_EXP ERIENCE

Jansen, D., Rosewell, J., \& Kear, K. (2016). Quality Frameworks for MOOCs. In: Open Educ. from OERs to MOOCs. Springer, Berlin, pp 261-281.

Jiang, S., Williams, A. E., Warschauer, M., He, W., \& O’Dowd, D. K. (2014). Influence of incentives on performance in a pre-college biology MOOC. The International Review of Research in Open and Distance Learning, 15(5). https:/ / doi.org/10.19173/irrodl.v15i5.1858

Jordan, K. (2014). Initial trends in enrolment and completion of massive open online courses. The International Review of Research in Open and Distributed Learning, 15(1). https:/ / doi.org/10.19173/irrodl.v15i1.1651

Kalman, Y. M. (2014). A race to the bottom: MOOCs and higher education business models. Open Learning: The Journal of Open, Distance and e-Learning, 29(1), 5-14. https:/ / doi.org/10.1080/02680513.2014.922410

Kay, J., Reimann, P., Diebold, E., \& Kummerfeld, B. (2013). MOOCs: So many learners, so much potential.... IEEE Intelligent Systems, 28(3), 70 -77. https:/ / doi.org/10.1109/MIS.2013.66 
Khalil, H., \& Ebner, M. (2014). MOOCs completion rates and possible methods to improve retention: A literature review. In World Conference on Educational Multimedia, Hypermedia and Telecommunications (pp. 1305-1313). https:/ / elearningblog.tugraz.at/archives/7354

King, N. (2012). Doing template analysis. Qualitative organizational research: Core methods and current challenges. In G. Symon \& C. Cassell (Eds.), Qualitative organizational research. Core methods and current challenges, Sage (pp. 426-450). https:/ / doi.org/10.4135/9781526435620.n24

Kizilcec, R., Piech, C., \& Schneider, E. (2013). Deconstructing disengagement: analyzing learner subpopulations in massive open online courses. In D. Suthers, K. Verbert, E. Duval \& X. Ochoa (Eds.), Proceedings of the Third International Conference on Learning Analytics and Knowledge, April 8-12, (pp.170-179). Leuven, Belgium. https:/ / doi.org/10.1145/2460296.2460330

Kolås, L., Nordseth, H., \& Hoem, J. (2016, September). Interactive modules in a MOOC. In Information Technology Based Higher Education and Training (ITHET), 2016 15th International Conference on (pp. 1-8). IEEE. https:// doi.org/10.1109/ITHET.2016.7760707

Kulkarni, C., Wei, K. P., Le, H., Chia, D., Papadopoulos, K., Cheng, J., . . Klemmer, S. R. (2013). Peer and selfassessment in massive online classes. ACM Transactions on Computer-Human Interaction (TOCHI), $20(6), 33$. https:/ / doi.org/10.1145/2505057

Kursun, E. (2016). Does formal credit work for MOOC-like learning environments? International Review of Research in Open and Distributed Learning, 17(3). https:/ / doi.org/10.19173/irrodl.v17i3.2403

Lackner, E., Ebner, M., \& Khalil, M. (2015). MOOCs as granular systems: Design patterns to foster participant $\begin{array}{llll}\text { activity. } \quad \text { Papers, 28-37. } & \text { 42, }\end{array}$ https:/ / pure.tugraz.at/portal/files/3217524/Design_Patterns_for_Open_Online_Teaching_and_Learning _In_Depth_42_3_1_.pdf

Li, N., Verma, H., Skevi, A., Zufferey, G., Blom, J., \& Dillenbourg, P. (2014). Watching MOOCs together: Investigating co-located MOOC study groups. Distance Education, 35(2), 217-233. https:// doi.org/10.1080/01587919.2014.917708

Lin, Y.-L., Lin, H.-W., \& Hung, T.-T. (2015). Value hierarchy for massive open online courses. Computers in Human Behaviour, 53, 408-418. https://doi.org/10.1016/j.chb.2015.07.006

Littlejohn, A., Hood, N., Milligan, C., \& Mustain, P. (2016). Learning in MOOCs: Motivations and self-regulated learning in MOOCs. The Internet and Higher Education, 29, 40-48. https://doi.org/10.1016/j.iheduc.2015.12.003

Liyanagunawardena, T. R., Adams, A. A., \& Williams, S. A. (2013). MOOCs: a systematic study of the published literature 2008-2012. The International Review of Research in Open and Distance Learning, 14(3), $202-227$. https:// doi.org/10.19173/irrodl.v14i3.1455

Liyanagunawardena, T. R., Lundqvist, K. Ø., \& Williams, S. A. (2015). Who are with us: MOOC learners on a FutureLearn course. British Journal of Educational Technology, 46(3), 557-569. https://doi.org/10.1111/bjet.12261

Maas, A., Heather, C., Do, C. T., Brandman, R., Koller, D., \& Ng, A. (2014). Offering verified credentials in massive open online courses: MOOCs and technology to advance learning and learning research (Ubiquity symposium). Ubiquity, 2014(May), 2. https:/ / doi.org/10.1145/2591684

Mackness, J., Waite, M., Roberts, G., \& Lovegrove, E. (2013). Learning in a small, task-oriented, connectivist MOOC: Pedagogical issues and implications for higher education. The International Review of Research in Open and Distributed Learning, 14(4). https:/ / doi.org/10.19173/irrodl.v14i4.1548

Mamgain, N., Sharma, A., \& Goyal, P. (2014, December). Learner's perspective on video-viewing features offered by MOOC providers: Coursera and edX. In MOOC, Innovation and Technology in Education (MITE), 2014 IEEE International Conference on (pp. 331-336). IEEE.

Margaryan, A., Bianco, M., \& Littlejohn, A. (2015). Instructional quality of massive open online courses (MOOCs). Computers E Education, 80, 77-83. https:/ / doi.org/10.1016/j.compedu.2014.08.005

Marshall, S. (2014). Exploring the ethical implications of MOOCs. Distance Education, 35(2), $250-262$. https:/ / doi.org/10.1080/01587919.2014.917706

Meyer, J. P., \& Zhu, S. (2013). Fair and equitable measurement of student learning in MOOCs: An introduction to item response theory, scale linking, and score equating. Research $\mathcal{E}$ Practice in Assessment, 8(1), 26-39. http:/ / files.eric.ed.gov/fulltext/EJ1062822.pdf

Milligan, C., Littlejohn, A., \& Margaryan, A. (2013). Patterns of engagement in connectivist MOOCs. MERLOT Journal of Online Learning and Teaching, 9(2), 149-159. Retrieved from http://jolt.merlot.org/vo19no2/abstracts.htm 
Moher, D., Liberati, A., Tetzlaff, J., Altman, D. G., \& Prisma Group. (2009). Preferred reporting items for systematic reviews and meta-analyses: the PRISMA statement. PLoS medicine, 6(7), e1000097. https://doi.org/10.1371/journal.pmed.1000097

Morris, N. P. (2014). How Digital Technologies, Blended Learning and MOOCs Will Impact the Future of Higher Education. International Association for Development of the Information Society.

Morris, N. P., Hotchkiss, S., \& Swinnerton, B. (2015). Can demographic information predict MOOC learner outcomes? In Proceedings of the European MOOC Stakeholder Summit (pp. 199-207).

Morris, N., \& Lambe, J. (2014). Palgrave study skills studying a MOOC: A guide. London, UK: Palgrave McMillan.

Munoz-Merino, P., Ruiperez-Valiente, J., Alario-Hoyos, C., Perez-Sanagustin, M., \& Delgado Kloos, C. (2015). Precise effectiveness strategy for analyzing the effectiveness of students with educational resources and activities in MOOCs. Computers in Human Behaviour, 47, 108-118. https:/ / doi.org/10.1016/j.chb.2014.10.003

Najafi, H., Rolheiser, C., Harrison, L., \& Håklev, S. (2015). University of Toronto instructors' experiences with developing MOOCs. The International Review of Research in Open and Distributed Learning, 16(3). https:/ / doi.org/10.19173/irrodl.v16i3.2073

Nelson, S. (2014). Measuring our first eight courses. Retrieved on December 15, 2015. Retrieved from https://about.futurelearn.com/blog/measuring-our-first-eight-courses/

North, S. M., Richardson, R., \& North, M. M. (2014). To adapt MOOCs, or not? That is no longer the question. Universal Journal of Educational Research, 2(1), 69-72. https:/ / www.learntechlib.org/p/160637

Parr, C. (2013). MOOCs Completion Rates „below 7\%"e, Times Higher Education. Retrieved from http:/ / www.timeshighereducation.co.uk/news/moocs-completion-ratesbelow- 7/2003710

Petticrew, M., \& Roberts, H. (2008). Systematic reviews in the social sciences: A practical guide. John Wiley \& Sons. https:// doi.org/10.1002/9780470754887

Phan, T., McNeil, S. G., \& Robin, B. R. (2016). Students' patterns of engagement and course performance in a Massive Open Online Course. Computers $\mathcal{E}$ Education, 95, 36-44. https:// doi.org/10.1016/j.compedu.2015.11.015

Piech, C., Huang, J., Chen, Z., Do, C., Ng, A., \& Koller, D. (2013). Tuned models of peer assessment in MOOCs. arXiv preprint arXiv:1307.2579.

Raffaghelli, J., Cucchiara, S., \& Persico, D. (2015). Methodological approaches in MOOC research: Retracing the myth of Proteus. British Journal of Educational Technologies, 46(3), 488-509. https:/ / doi.org/10.1111/bjet.12279

Raposo-Rivas, M., Martinez-Figueira, E., \& Campos, J. A. S. (2015). A study on the pedagogical components of massive online courses. Comunicar, 44, 27-35. https:/ / doi.org/10.3916/c44-2015-03

Reich, J. (2014). MOOC completion and retention in the context of student intent. EDUCAUSEreview online. Retrieved from http://www.educause.edu/ero/article/mooc-completion-and-retention-context-studentintent

Reilly, E. D., Stafford, R. E., Williams, K. M., \& Corliss, S. B. (2014). Evaluating the validity and applicability of automated essay scoring in two massive open online courses. The International Review of Research in Open and Distance Learning, 15(5), 83-98. https:/ / doi.org/10.19173/irrodl.v15i5.1857

Rivard, R. (2013). No-bid MOOCs. Inside Higher Ed. Retrieved from http:/ / www.insidehighered.com/news/2013/07/17/MOOCs-spread-quickly-aided-no-bid-dealspublicuniversities

Rodriguez, C. O. (2012). MOOCs and the AI-Stanford like courses: Two successful and distinct course formats for massive open online courses. European Journal of Open, Distance and E-Learning, 15(2). Retrieved from http:/ / files.eric.ed.gov/fulltext/ EJ982976.pdf

Ross, J., Sinclair, C., Knox, J., \& Macleod, H. (2014). Teacher experiences and academic identity: The missing components of MOOC pedagogy. Journal of Online Learning and Teaching, 10(1), 57. Retrieved from http:/ / www.jolt.merlot.org/vol10no1/ross_0314.pdf

Sandeen, C. (2013a). Assessment's place in the new MOOC world. Research E Practice in Assessment Journal, 8, 5-13. Retrieved from http:/ /www.rpajournal.com/dev/wp-content/uploads/2013/05/SF1.pdf

Sandeen, C. (2013b). Integrating MOOCS into traditional higher education: The emerging "MOOC 3.0" era. Change: The Magazine of Higher Learning, 45(6), 34-39. https:/ / doi.org/10.1080/00091383.2013.842103

Schulze, A. S. (2014). Massive open online courses (MOOCs) and completion rates: Are self-directed adult learners the most successful at MOOCs? (Unpublished doctoral dissertation, Pepperdine University, California). Retrieved from ProQuest Dissertations \& Theses Global. (1549976283) 
Sharples, M., Adams, A., Ferguson, R., Gaved, M., McAndrew, P., Rienties, B., Weller, M., \& Whitelock, D. (2014). Innovating Pedagogy 2014: Open University Innovation Report 3. Milton Keynes: The Open University.

Sharples, M., McAndrew, P., Weller, M., Ferguson, R., FitzGerald, E., Hirst, T., \& Gaved, M. (2013). Innovating Pedagogy 2013: Open University Innovation Report 2. Milton Keynes: The Open University.

Shen, C., \& Kuo, C. (2015). Learning in massive open online courses: Evidence from social media mining. Computers in Human Behavior, 51, 568-577. https:/ / doi.org/10.1016/j.chb.2015.02.066

Tabba, Y., \& Medouri, A. (2013). LASyM: A learning analytics system for MOOCs. International Journal of Advanced Computer Science and Applications, 4(5), 113-119. https:/ / doi.org/10.14569/IJACSA.2013.040516

Toven-Lindsey, B., Rhoads, R. A., \& Lozano, J. B. (2015). Virtually unlimited classrooms: Pedagogical practices in massive open online courses. The Internet and Higher Education, 24, 1-12. https:// doi.org/10.1016/j.iheduc.2014.07.001

Veletsianos, G., \& Shepherdson, P. (2016). A Systematic Analysis and Synthesis of the Empirical MOOC Literature Published in 2013-2015. The International Review of Research in Open and Distributed Learning, 17(2). https:// doi.org/10.19173/irrodl.v17i2.2448

Veletsianos, G., Collier, A., \& Schneider, E. (2015). Digging deeper into learners' experiences in MOOCs: Participation in social networks outside of MOOCs, notetaking and contexts surrounding content consumption. British Journal of Educational Technology, 46(3), 570-587. https:/ / doi.org/10.1111/bjet.12297

Waite, M., Mackness, J., Roberts, G., \& Lovegrove, E. (2013). Liminal participants and skilled orienteers: Learner participation in a MOOC for new lecturers. Journal of Online Learning and Teaching, 9(2), 200-215. http://jolt.merlot.org/vo19no2/waite_0613.htm

Wen, M., Yang, D., \& Rosé, D. (2014b). Linguistic Reflections of Student Engagement in Massive Open Online Courses. In Proceedings of the International Conference on Weblogs and Social Media. Retrieved from http:/ / www.cs.cmu.edu/ mwen/papers/icwsm2014-camera-ready.pdf

Young, J. R. (2013). Beyond the MOOC hype: A guide to higher education's high-tech disruption. The Chronicle of Higher Education.

Yousef, A. M. F., Chatti, M. A., Schroeder, U., \& Wosnitza, M. (2014c). What Drives a Successful MOOC? An Empirical Examination of Criteria to Assure Design Quality of MOOCs. In Advanced Learning Technologies (ICALT), 2014 IEEE 14th International Conference on (pp. 44-48). IEEE. https:// doi.org/10.1109/ICALT.2014.23

Yousef, A. M. F., Chatti, M. A., Schroeder, U., Wosnitza, M., \& Jakobs, H. (2014b). MOOC - A Review of the Stateof-the-Art. In Proceedings of the CSEDU 2014 conference, Vol. 3, pp. 9-20. INSTICC, 2014.

Yousef, A. M. F., Wahid, U., Chatti, M. A., Schroeder, U., \& Wosnitza, M. (2015e). The Effect of Peer Assessment Rubrics on Learners' Satisfaction and Performance within a Blended MOOC Environment. In Proceedings of the CSEDU 2015 conference, (pp. 148-159). INSTICC, 2015. https:/ / doi.org/10.5220/0005495501480159

Yuan, L., \& Powell, S. (2013). MOOCs and open education: Implications for higher education. JISC Cetis, UK. https:/ / doi.org/10.13140/2.1.5072.8320

Yusop, F. D. (2015). A dataset of factors that influence preservice teachers' intentions to use Web 2.0 technologies in future teaching practices. British Journal of Educational Technology, 46(5), 1075-1080. https://doi.org/10.1111/bjet.12330

Yusop, F. D., \& Siti Mariam, M. A. B. (2017). Resistance towards wiki: implications for designing successful wikisupported collaborative learning experiences. Universal Access in the Information Society (UAIS), 16(2), 349360. https:// doi.org/10.1007/s10209-016-0462-3

Zheng, S., Rosson, M. B., Shih, P. C., \& Carroll, J. M. (2015). Understanding student motivation, behaviors and perceptions in MOOCs. Proceedings of the 18th ACM Conference on Computer Supported Cooperative Work $\mathcal{E}$ Social Computing March 14 - 18, 2015 (pp. 1882-1895). Vancouver, BC, Canada. https:/ / doi.org/10.1145/2675133.2675217

\section{http://www.ejmste.com}

